\title{
Effect of dietary supplementation of trace elements on blood chemistry and selected immunological indices depending on the age of broiler chickens
}

\author{
Vladimír Petrovič ${ }^{1}$, Ján Kushev², Lode Nollet ${ }^{3}$, Gabriel Kováč ${ }^{1}$ \\ ${ }^{1}$ Clinic for Ruminants, ${ }^{2} 1^{\text {st }}$ Internal Clinic, University of Veterinary Medicine and Pharmacy, \\ Košice, Slovak Republic \\ ${ }^{3}$ Alltech Netherlands BV, Belgian Office, Deinze, Belgium
}

Received June 6, 2009

Accepted September 21, 2010

\begin{abstract}
This study was performed to determine the effects of dietary supplementation of $\mathrm{Cu}, \mathrm{Zn}, \mathrm{Fe}$, Mn and Se on some haematological, immunological and enzymatic indices in blood of broilers at the age of 21, 35 and 42 days. The basal diets (BDs) for Groups 1 and 2 were supplemented with the equivalent amounts of trace elements in an inorganic form $\left(\mathrm{Cu}\right.$ sulphate $5 \mathrm{mg} \cdot \mathrm{kg}^{-1} \mathrm{DM}$, Fe sulphate, $\mathrm{Zn}$ oxide, Mn oxide $50 \mathrm{mg} \cdot \mathrm{kg}^{-1} \mathrm{DM}$ ), however sodium selenite or selenized yeast (Sel-Plex) were given at a dose of Se $0.3 \mathrm{mg} \cdot \mathrm{kg}^{-1} \mathrm{DM}$, respectively. Groups 3 and 4 received the same BD's but with the substantially reduced amount of supplemented nutrients in the organic "proteinated" form (Bioplex $\mathrm{Cu} 2.5 \mathrm{mg} \cdot \mathrm{kg}^{-1} \mathrm{DM}$, Bioplex Fe, Bioplex Zn, Bioplex Mn $10 \mathrm{mg} \cdot \mathrm{kg}^{-1} \mathrm{DM}$ ), except for selenium that was given at a dose of Se $0.3 \mathrm{mg} \cdot \mathrm{kg}^{-1} \mathrm{DM}$ as sodium selenite or Sel-Plex, respectively. The supplementation of restricted doses of trace elements in the organic forms into the diet did not affect studied haematological, immunological, enzymatic indices. At the age of 21 days, the activity of GSH-Px was significantly higher in the groups supplemented with sodium selenite later no differences due to the administered form of Se were found. This indicates that the GSH-Px activity reached a plateau in all groups of broilers at the 21, 35 and 42 day, except for GSH-Px activity in the groups of birds supplemented with selenized yeast on day 21. In Addition, significant age dependent changes were observed in blood chemistry, but the different treatments did not influence these changes. Base on our results, the doses of organic forms of trace elements supplemented into the diets for poultry can be restricted to 50\% (Bioplex $\mathrm{Cu}$ ) and 20\% (Bioplex Fe, Bioplex Zn and Bioplex Mn) without influencing the blood chemistry of broilers.
\end{abstract}

Poultry, mineral nutrients, proteinated forms, age dependent haematological, immunological and enzymatic changes

During the last decades, the diets for broilers have been routinely supplemented with trace elements in the form of inorganic salts to avoid mineral deficiency. Based on the facts that organic "proteinated" forms of trace elements have at least 30\% higher bioavailability (Leeson and Caston 2003) and their excretion from the organism of bird via feces is significantly lower than their inorganic salts (Nollet et al. 2005), the use of organic forms of trace elements in the poultry nutrition has been suggested.

The recent experiments performed on broilers showed that the supplementation of diets with the substantially reduced doses of trace elements $(\mathrm{Cu}, \mathrm{Fe}, \mathrm{Zn}$ and $\mathrm{Mn})$ in the organic forms has the same effect on the growth performance of broilers (Peric et al. 2006; Nollet et al. 2007 and 2008) and on their concentration in the muscles (Petrovič et al. 2010) as the feeding of diets with the recommended doses of their mineral salts. However, selenized yeast is able to build significant Se deposits in the muscle of poultry compared to sodium selenite (Kuricová et al. 1999; Sevcikova et al. 2006; Petrovič et al. 2006; Petrovič et al. 2010).

Some trace elements (especially $\mathrm{Cu}, \mathrm{Zn}$ and $\mathrm{Se}$ ) markedly influence humoral and cellular immunity (Sandstead 1994; Allgöwer et al. 1995). It is well known that deficiency of trace elements decreases the antibody production, $\mathrm{T}$ cell proliferation response to

Address for correspondence:

Vladimír Petrovič, DVM., PhD.

University of Veterinary Medicine and Pharmacy

Clinic for Ruminants

Komenského 73, 041 81, Košice

Slovak Republik 
mitogens, neutrophil function and the natural killer cell activity (Chandra and McBean 1994). Fekete and Kellems (2007) found that a lack of copper, iron, zinc and selenium in the animal organism is associated with signs of immunodeficiency. In addition, the trace elements $(\mathrm{Cu}, \mathrm{Zn} . \mathrm{Fe}, \mathrm{Mn}$ and $\mathrm{Se})$ are involved in the metabolic activities via metalloenzymes (Cu-Zn SOD, Mn SOD, Catalase, GSH-Px, etc.) which are essential for the antioxidant protection of cells in poultry (Ozturk-Urek et al. 2001). For these reasons, it is questionable whether a reduced intake of trace elements in diet can significantly affect the haematological, immunological and enzymatic indices in blood of broiler chickens at different phases of their life.

The aim of this study was to determine the effect of dietary supplementation of $\mathrm{Cu}, \mathrm{Zn}$, $\mathrm{Fe}, \mathrm{Mn}$ and Se on selected haematological, immunological and enzymatic indices in blood of broiler chickens Ross 308 at the age of 21,35 and 42 days.

Animals, diets and treatments

\section{Materials and Methods}

Two hundred unsexed Ross 308 broilers were randomly divided on the day of hatching into 4 groups $(n=50$ per group) and were fed for 42 days diets containing different amounts and forms of $\mathrm{Cu}, \mathrm{Fe}, \mathrm{Zn}, \mathrm{Mn}$ and $\mathrm{Se}$. The diets were fed ad libitum during the whole experimental period. The broiler feed "Starter" was fed until day 21, the broiler feed "Grower" until day 35 and the broiler feed "Finisher" until day 42, respectively. Bioplex Cu, Bioplex Fe, Bioplex Zn, Bioplex Mn and Sel-Plex were purchased from Alltech Inc., Belgium. Feeds were produced at Research Diets Services (RDS), Wijk bij Duurstede, The Netherlands. All premixes were fortified with phytase and xylanase, and a coccidiostatic preparation was added into the diets fed until day 35 . The composition of all diets is presented in Table 1.

Table 1. Composition of basal diets fed to Ross 308 broilers during the whole experiment.

\begin{tabular}{lccc}
\hline $\begin{array}{l}\text { Component } \\
\left(\mathrm{g} \cdot \mathrm{kg}^{-1} \mathrm{DM}\right)\end{array}$ & $\begin{array}{c}\text { Starter } \\
(1-21 \text { day })\end{array}$ & $\begin{array}{c}\text { Grower } \\
(21-35 \text { day })\end{array}$ & $\begin{array}{c}\text { Finisher } \\
(35-42 \text { day })\end{array}$ \\
\hline Wheat & 534.5 & 566.6 & 566.6 \\
Peas & 100 & 100 & 100 \\
Rape seed meal (32\% CP) & 30 & 25 & 25 \\
Soybean meal (46.5\% CP, 1.5\% fat) & 250 & 220 & 220 \\
Palm oil & 25 & 35 & 35 \\
Soya oil & 25 & 25 & 25 \\
Premix & 5 & 5 & 5 \\
Limestone & 14.5 & 11.5 & 3.5 \\
Monocalcium phosphate & 8 & 3.5 & 0.1 \\
Natuphos 5000G (phytase) & 0.1 & 0.1 & 2.2 \\
NaCl & 2.2 & 2.2 & 2 \\
NaHCO & 2 & 2 & 1.5 \\
L-lysine & 1.5 & 1.5 & 2 \\
DL-methionine & 2 & 2 & 0.6 \\
L-threonine & 0.5 & 0.6 & 5 \\
\hline
\end{tabular}

$1 \mathrm{~kg}$ of basal diet contained: dry matter $879 \mathrm{~g}$; crude protein $201 \mathrm{~g}$; crude fat, $73 \mathrm{~g}$; ash, $45 \mathrm{~g}$; crude fibre, $31 \mathrm{~g}$; 12.31 MJ; lysine $11.3 \mathrm{~g}$; methionine, $4.8 \mathrm{~g}$; methionine+cystine, $8.2 \mathrm{~g}$; threonine, $7.6 \mathrm{~g}$; tryptophan, $2.4 \mathrm{~g}$; valine, 9 g; arginine, 12.9; histidine, 5 g; Ca, 6.8 g; P, 4.5 g; Na, 1.5 g; K, 8.6 g; Cl-, 2 g; Cu, 10 mg; Fe, 150 mg; Zn, 35 $\mathrm{mg} ; \mathrm{Mn}, 15 \mathrm{mg}$; Se, $0.1 \mathrm{mg}$

aPremix supplied per kg of basal diet: vitamin A, $10000 \mathrm{IU}$; vitamin $\mathrm{D}_{3}, 3000 \mathrm{IU}$; vitamin E, $20 \mathrm{mg}$; vitamin K, $3 \mathrm{mg}$; tiamine, $2 \mathrm{mg}$; riboflavin, $8 \mathrm{mg}$; niacin, $15 \mathrm{mg}$; cholinchlorid, $50 \mathrm{mg}$; pantothenic acid, $50 \mathrm{mg}$; pyridoxine, $5 \mathrm{mg}$; folic acid, $2 \mathrm{mg}$; cyanocobalamin, $30 \mu \mathrm{g}$; biotin, $0.2 \mathrm{mg}$; I, $2 \mathrm{mg}$; Co, $1 \mathrm{mg}$

Broilers in Groups 1 and 2 were fed the diet supplemented with $\mathrm{Cu} 5 \mathrm{mg} \cdot \mathrm{kg}^{-1}$ dry matter (DM) (Cu sulphate), $\mathrm{Fe}, \mathrm{Zn}$, Mn $50 \mathrm{mg} \cdot \mathrm{kg}^{-1} \mathrm{DM}$ (Fe sulphate, Zn oxide, Mn oxide) and Se $0.3 \mathrm{mg} \cdot \mathrm{kg}^{-1} \mathrm{DM}$ in a form of sodium selenite or selenized yeast (Sel-Plex), respectively. Groups 3 and 4 received the same feed supplemented with substantially reduced dose of trace elements (except of Se) in the proteinated forms: $\mathrm{Cu} 2.5 \mathrm{mg} \cdot \mathrm{kg}^{-1} \mathrm{DM}$ (Bioplex 
$\mathrm{Cu}$ ), Fe, Zn, Mn $10 \mathrm{mg} \cdot \mathrm{kg}^{-1} \mathrm{DM}$ (Bioplex Fe, Bioplex Zn, Bioplex Mn) and Se $0.3 \mathrm{mg} \cdot \mathrm{kg}^{-1} \mathrm{DM}$ in the form of sodium selenite or Sel-Plex, respectively.

On day 1 after hatching, the broilers were placed in one-level cages. The lighting regime was 23L:1D till the end of the experiment. The initial room temperature of $32{ }^{\circ} \mathrm{C}$ was reduced every week by $3{ }^{\circ} \mathrm{C}$ to final $22-23{ }^{\circ} \mathrm{C}$. All birds had free access to feed and water. From day 2 to day 5 of life, the chickens received an

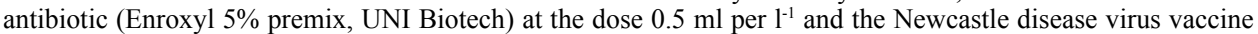
(AVIPEST Lyof., Mevak a.s.) was administered on day 18. Both preparations were given into the drinking water. The protocol was approved by local Ethics Committee.

\section{Sample analysis}

The blood indices (haemoglobin, red blood cell count, mean corpuscular haemoglobin value, white blood cell (WBC) count were assessed by the blood counter (ABC VET 16p, Trigon s.r.o.). The lymphocytes and neutrophils were counted per $100 \mathrm{WBC}$ in a Burker chamber. The antibodies against the Newcastle disease virus and egg drop syndrom were detected by haemagglutination-inhibition test. The antibodies against the infectious bursal disease virus, infectious bronchitis virus, avian reovirus, Mycoplasma gallisepticum and Mycoplasma synoviae were examined using the enzyme-linked immunosorbent assay (ELISA) kits (BioChek, Gouda, Holland). Salmonella pullorum antibodies were determined by quick slide agglutination test.

The metabolic activity of phagocytes (index of metabolic activity of phagocytes) during phagocytosis was determined on the base of quantitative evaluation of iodo-nitro-tetrazolium reductase activity of phagocytes according to method described by Goldová et al. (2001). The lymphoproliferation test (stimulation index of lymphocytes) is a colorimetric immunoassay used to quantify cell proliferation. This method is based on the measurement of 5-bromo-2-deoxyuridine (BrdU) incorporation into the lymphocytes during the synthesis of DNA (Cell Proliferation ELISA Kit, BrdU-colorimetric, Roch Diagnostics, GmbH, Germany). The optical density was measured at $450 \mathrm{~nm}$ by ELISA-multiwell reader (BIO-RAD Laboratories, Inc.,USA). The stimulation index of lymphocytes was calculated on the basis of the ratio of absorbance of the stimulated cells to the non-stimulated cells (Barta et al., 1992).

The standard kits from Randox, UK were used to determine the activities of aspartate aminotransferase (AST, EC 2.3.1.1), alanine aminotrasferase (ALT, EC 2.6.1.2), gamma glutamyltransferase ( $\gamma \mathrm{GT}$, EC 2.3.2.2), alkaline phosphatase (ALP, EC 3.1.3.1), lactate dehydrogenase (LDH, EC 1.1.1.27) and creatine phosphokinase (CPK, EC 2.7.3.2), in the blood serum. Activity of blood glutathione peroxidase (GSH-Px, EC 1.11.1.9) was determined using the Ransel kit (Randox, UK). Haemoglobin $(\mathrm{Hb})$ content of blood and superoxide dismutase (SOD, EC 1.15.1.1) activities (Arthur and Boyne, 1985) in erythrocytes were analyzed using kits from Randox, UK. All studied enzymatic indexes were determined by automatic spectrometer Alizé (Lisabio, Fr.).

Statistical analysis

One-way analysis of variance (ANOVA) with the post hoc Tukey's multiple comparison test was used for the statistical analysis between the experimental groups on days 21,35 and 42 of age. Significant changes within each treatment were found by the paired Student's t-test comparing day 21 vs. day 35, and day 35 vs. day 42 . The statistical software GrafPad Prism, Version 4.00 (2003) was applied in both cases.

\section{Results and Discussion}

The feeding of diet supplemented with substantially reduced doses of nutrients in the organic form has the same effect on all studied haematological indexes and the titres of antibodies against the infectious agents of poultry in the blood serum of broilers at the age of 21,35 and 42 days as the feeding of regular doses of trace elements in the forms of their mineral salts (Tables 2 and 3 ).

Microelements contribute to the immunocompetence of organism (Munoz et al. 2007). As mentioned above, the higher bioavailability of the organic forms of the elements could be taken as a possible explanation of our findings. Ševčíková et al. (2005) found an improved immune response of chickens fed a diet supplemented with inorganic as well as organic form of selenium. Similarly, no differences were observed in the assessed immunological indices in our experiment due to the form of Se administered in the diet for broilers at the age of 21, 35 and 42 days. Moreover, supplementation of the diets for broilers with substantially reduced doses of trace elements $(\mathrm{Cu}, \mathrm{Zn}, \mathrm{Fe}$ and $\mathrm{Mn})$ in the proteinated forms had the same effect on the haematoligical and immunological indices as the feeding of diets with recommended doses of their inorganic salts.

Age dependent changes in some of the studied haematological and immunological indices were found in our experiment, nevertheless these changes were not affected by the different dietary treatment (Tables 2 and 3). Red blood cell and white blood cell counts were 
Table 2. The effects of supplementation of the diet with different form and amount of $\mathrm{Cu}, \mathrm{Fe}, \mathrm{Zn}, \mathrm{Mn}$ and $\mathrm{Se}$ on haemoglobin $(\mathrm{Hb})$, red blood cell (RBC) count, mean corpuscular haemoglobin concentration (MCHC), white blood cell (WBC) count, lymphocytes (Lym.), neutrophils (Neut.), iodo-nitro-tetrazolium reductase test (INT) and lymphoproliferation test (LPT) in blood of broiler chickens at the day 21, 35 and 42 .

\begin{tabular}{|c|c|c|c|c|c|c|c|c|}
\hline & \multicolumn{8}{|c|}{ Index } \\
\hline & $\begin{array}{c}\mathrm{Hb} \\
\left(\mathrm{g} \cdot \mathrm{dl}^{-1}\right)\end{array}$ & $\begin{array}{l}\text { RBC } \\
\left(\mathrm{T} \cdot 1^{-1}\right) \\
\end{array}$ & $\begin{array}{l}\mathrm{MCHC} \\
\left(\mathrm{g} \cdot \mathrm{dl}^{-1}\right)\end{array}$ & $\begin{array}{l}\text { WBC } \\
\left(G \cdot 1^{-1}\right)\end{array}$ & $\begin{array}{c}\text { Lym. } \\
(\%)\end{array}$ & $\begin{array}{c}\text { Neut. } \\
(\%)\end{array}$ & $\begin{array}{c}\text { INT } \\
\text { a(IMA) }\end{array}$ & $\begin{array}{l}\text { LPT } \\
\text { b(SI) } \\
\end{array}$ \\
\hline \multicolumn{9}{|c|}{ Day 21} \\
\hline \multirow{2}{*}{ Group 1} & 4.9 & 1.81 & 36.0 & 17.6 & 68.7 & 25.3 & 2.7 & 3.11 \\
\hline & \pm 1.28 & \pm 0.16 & \pm 2.0 & \pm 4.3 & \pm 11.5 & \pm 6.0 & \pm 0.3 & \pm 0.29 \\
\hline \multirow{2}{*}{ Group 2} & 4.65 & 1.75 & 35.2 & 15.9 & 61.5 & 32.0 & 2.65 & 3.18 \\
\hline & \pm 0.76 & \pm 0.45 & \pm 2.1 & \pm 4.8 & \pm 6.4 & \pm 7.9 & \pm 0.29 & \pm 0.39 \\
\hline \multirow{2}{*}{ Group 3} & 4.82 & 1.94 & 35.1 & 15.4 & 66.5 & 26.5 & 2.69 & 3.12 \\
\hline & \pm 1.43 & \pm 0.36 & \pm 2.8 & \pm 3.2 & \pm 7.1 & \pm 6.8 & \pm 0.41 & \pm 0.33 \\
\hline \multirow{3}{*}{ Group 4} & 5.66 & 1.59 & 34.0 & 14.7 & 63.0 & 31.3 & 2.74 & 3.11 \\
\hline & \pm 0.96 & \pm 0.3 & \pm 1.9 & \pm 3.6 & \pm 7.8 & \pm 8.2 & \pm 0.41 & \pm 0.32 \\
\hline & & & & Day 35 & & & & \\
\hline \multirow{2}{*}{ Group 1} & 5.65 & 1.54 & 39.1 & 20.4 & 62.0 & 34.8 & 2.8 & 3.13 \\
\hline & \pm 1.01 & \pm 0.21 & $\pm 2.4^{* *}$ & \pm 3.2 & \pm 7.7 & \pm 8.1 & \pm 0.51 & \pm 0.34 \\
\hline \multirow{2}{*}{ Group 2} & 5.45 & 1.38 & 39.4 & 20.8 & 63.1 & 32.3 & 2.92 & 3.38 \\
\hline & \pm 1.19 & \pm 0.25 & $\pm 2.2^{* *}$ & \pm 3.3 & \pm 3.7 & \pm 10.1 & \pm 0.4 & \pm 0.41 \\
\hline \multirow{2}{*}{ Group 3} & 5.07 & 1.79 & 39.8 & 19.7 & 66.9 & 29.9 & 2.86 & 3.26 \\
\hline & \pm 1.3 & \pm 0.3 & $\pm 1.9^{* *}$ & \pm 2.5 & \pm 10.4 & \pm 9.4 & \pm 0.4 & \pm 0.36 \\
\hline \multirow{3}{*}{ Group 4} & 5.29 & 1.58 & 39.0 & 18.2 & 62.6 & 28.6 & 2.91 & 3.26 \\
\hline & \pm 1.25 & \pm 0.22 & $\pm 2.2^{* *}$ & \pm 3.8 & \pm 14.1 & \pm 6.8 & \pm 0.44 & \pm 0.51 \\
\hline & & & & Day 42 & & & & \\
\hline \multirow{2}{*}{ Group 1} & 5.01 & 2.28 & 40.3 & 26.3 & 69.0 & 28.2 & 2.75 & 3.18 \\
\hline & \pm 0.83 & $\pm 0.27^{*}$ & \pm 2.1 & $\pm 5.7^{* * *}$ & \pm 6.8 & \pm 7.1 & \pm 0.39 & \pm 0.32 \\
\hline \multirow{2}{*}{ Group 2} & 4.77 & 2.06 & 39.5 & 26.6 & 69.7 & 22.9 & 3.09 & 3.45 \\
\hline & \pm 1.06 & $\pm 0.31^{*}$ & \pm 1.8 & $\pm 4.4^{* * *}$ & \pm 5.8 & \pm 4.9 & \pm 0.38 & \pm 0.37 \\
\hline \multirow{2}{*}{ Group 3} & 5.06 & 2.22 & 40.5 & 23.2 & 62.9 & 28.8 & 2.78 & 3.29 \\
\hline & \pm 0.77 & $\pm 0.23^{*}$ & \pm 1.6 & $\pm 5.5^{* * *}$ & \pm 12.2 & \pm 10.5 & \pm 0.38 & \pm 0.22 \\
\hline \multirow{2}{*}{ Group 4} & 5.45 & 2.17 & 39.1 & 24.9 & 64.1 & 23.5 & 2.98 & 3.36 \\
\hline & \pm 0.93 & $\pm 0.27^{*}$ & \pm 1.9 & $\pm 2.5^{* * *}$ & \pm 8.8 & \pm 7.1 & \pm 0.4 & \pm 0.39 \\
\hline
\end{tabular}

Results are presented as mean \pm S.D., $\mathrm{n}=15$

Significant differences at the day 21 vs. day 36 , and the day 36 vs. day $42(* P<0.05 ; * * P<0.01 ; * * * P<0.001)$ aIMA - index of metabolic activity of phagocytes (ration of heterophils with and without phagocyted starch),

${ }^{\mathrm{b}} \mathrm{SI}$ - stimulation index of lymphocytes (ration of stimulated to non-stimulated cells)

significantly increased at the $42^{\text {nd }}$ day compared to the $35^{\text {th }}$ day of life of broilers, whereas a significant increase in the mean corpuscular haemoglobin concentration was found between the earlier samplings. We can predict that the increased saturation of erytrocytes with $\mathrm{Hb}$ and the subsequent increase of RBC count (probably caused by the elevated erytropoesis) reflect the reaction of organism to the intensive growth performance of broilers during the final phase of fattening (Petrovič et al. 2010). On the other hand, the Newcastle disease virus (NDV) vaccine applied on the $18^{\text {th }}$ day of life of broilers caused a significant increase in the titres of antibodies against NDV at the $35^{\text {th }}$ and $42^{\text {nd }}$ day of life. The titres of infectious bursal disease virus (IBDV) antibodies significantly increased in the blood serum of broilers at the day 21 in comparison to the day 35, although we did not vaccinate the birds against this disease. Our explanation is based on the transovarial transfer of maternal antibodies into egg yolk (Lasher and Shane 1994), as a result of routine vaccination of 
Table 3. The effects of supplementation of the diet with different form and amount of $\mathrm{Cu}, \mathrm{Fe}, \mathrm{Zn}, \mathrm{Mn}$ and Se on the titres of antibodies against the Newcastle disease virus (NDV) and infectious bursal disease virus (IBDV) in the blood serum of broiler chickens at the day 21,35 and 42 .

\begin{tabular}{lcc}
\hline & \multicolumn{2}{c}{ Infectious agents $\left(\log _{2}\right)$} \\
\hline & NDV & IBDV \\
\hline Droup 1 & $1: 2$ & $1: 512$ \\
Group 2 & $1: 2$ & $1: 512$ \\
Group 3 & $1: 2$ & $1: 512$ \\
Group 4 & $1: 2$ & $1: 512$ \\
& Day 35 & \\
Group 1 & $1: 128^{* * *}$ & $1: 1^{* * *}$ \\
Group 2 & $1: 128^{* * *}$ & $1: 1^{* * *}$ \\
Group 3 & $1: 128^{* * *}$ & $1: 1^{* * *}$ \\
Group 4 & $1: 128^{* * *}$ & $1: 1^{* * *}$ \\
Group 1 & Day 42 & \\
Group 2 & $1: 128$ & $1: 1$ \\
Group 3 & $1: 128$ & $1: 1$ \\
Group 4 & $1: 128$ & $1: 1$ \\
\hline
\end{tabular}

Results are presented as mean titers of antibodies, $\mathrm{n}=6$

Significant differences at the day 21 vs. day 36 , and the day 36 vs. day $42(* * * P<0.001)$

breeder flocks with IBDV vaccine just before egg production. Moreover, the substantially reduced doses of $\mathrm{Cu}, \mathrm{Fe}, \mathrm{Zn}$ and $\mathrm{Mn}$ in the organic forms which were supplemented with the recommended dose of selenium into the diets did not decrease the immunity of birds in our experiment. Negative titres of antibodies against the infectious bronchitis virus, avian reovirus, Mycoplasma gallisepticum, Mycoplasma synoviae, Salmonella pullorum, egg drop syndrome that were detected in the blood serum of broiler chickens at the age of 21,35 and 42 days can confirm this fact.

At the day 21, the activity of blood glutathione peroxidase (GSH-Px) was found to be significantly higher in chickens supplemented with $\mathrm{Na}_{2} \mathrm{SeO}_{3}$ compared to selenized yeast, thereafter no differences due to the form of Se administered were found, indicating that the GSH-Px activity reaches a plateau in all groups of broilers (Fig. 1). The deficiency of $\mathrm{Cu}, \mathrm{Zn}, \mathrm{Fe}$ and Se significantly influences the activity of antioxidant enzymes (GSH-Px and superoxide dismutase) and lipid peroxidation in the erytrocytes of broilers (Bozkaya et al. 2001). Furthermore, it is well known that sodium selenite as well as selenized yeast "selenomethionine" must be split to selenide $\left(\mathrm{H}_{2} \mathrm{Se}\right)$ before selenocysteine is de novo synthetized and subsequently specifically incorporated into the active center of selenoenzymes (Schrauzer 2000). The significantly elevated GSH-Px activity in blood of broilers receiving diets enriched with the organic form of Se was found only at the day 35 vs. day 21 . It could

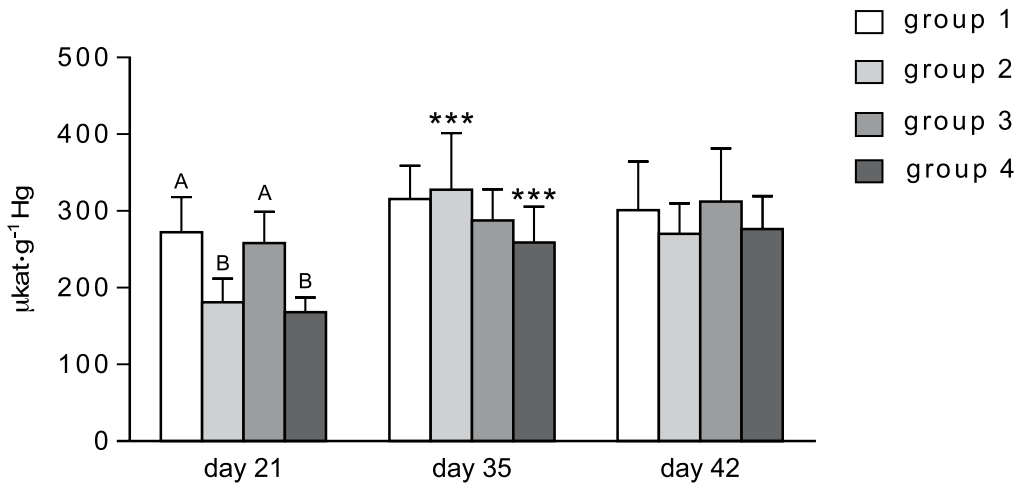

Fig. 1. The effects of supplementation of the diet for broiler chickens with different form and amount of $\mathrm{Cu}, \mathrm{Fe}$, $\mathrm{Zn}, \mathrm{Mn}$ and Se on the activity of GSH-Px in blood of broiler chickens at the day 21, 35 and 42.

Values are means \pm S.D., $\mathrm{n}=15$ in each group. Distinct letters and signs above columns mean significant differences between the treatments at the age of 21,35 and 42 days ( ${ }^{\mathrm{XY}} P<0.001$ ) and the statistical differences between the groups of chickens at the day $21 \mathrm{vs}$. day 35 and the day $35 \mathrm{vs}$. day $42(* * * P<0.001)$. 
Table 4. The effects of supplementation of the diet with different form and amount of $\mathrm{Cu}, \mathrm{Fe}, \mathrm{Zn}, \mathrm{Mn}$ and $\mathrm{Se}$ on the activities of aspartate aminotransferase (AST), alanine aminotrasferase (ALT), gamma glutamyltransferase $(\gamma \mathrm{GT})$, alkaline phosphatase (ALP), lactate dehydrogenase (LDH) and creatine phosphokinase (CPK) in the blood serum of broiler chickens at the day 21,35 and 42 .

\begin{tabular}{|c|c|c|c|c|c|c|}
\hline & \multicolumn{6}{|c|}{ Enzymes $\left(\mu \mathrm{kat} \cdot \mathrm{l}^{-1}\right)$} \\
\hline & AST & ALT & $\gamma \mathrm{GT}$ & ALP & $\mathrm{LDH}$ & CPK \\
\hline \multirow{3}{*}{ Group 1} & & & Day 21 & & & \\
\hline & 4.63 & 0.16 & 0.50 & 198.9 & 73.1 & 152.5 \\
\hline & \pm 1.07 & \pm 0.04 & \pm 0.09 & \pm 79.4 & \pm 21.2 & \pm 42.0 \\
\hline \multirow{2}{*}{ Group 2} & 4.36 & 0.17 & 0.45 & 212.8 & 58.9 & 127.5 \\
\hline & \pm 0.56 & \pm 0.07 & \pm 0.11 & \pm 76.7 & \pm 10.4 & \pm 31.7 \\
\hline \multirow{2}{*}{ Group 3} & 4.01 & 0.20 & 0.43 & 181.9 & 76.7 & 131.7 \\
\hline & \pm 0.31 & \pm 0.06 & \pm 0.06 & \pm 79.1 & \pm 23.4 & \pm 28.2 \\
\hline \multirow{3}{*}{ Group 4} & 4.79 & 0.17 & 0.47 & 201.9 & 59.5 & 118.7 \\
\hline & \pm 0.37 & \pm 0.05 & \pm 0.06 & \pm 86.9 & \pm 14.6 & \pm 29.6 \\
\hline & & & Day 35 & & & \\
\hline \multirow{2}{*}{ Group 1} & 4.34 & 0.18 & 0.51 & 101.7 & 106.1 & 303.72 \\
\hline & \pm 0.47 & \pm 0.03 & \pm 0.09 & $\pm 44.9^{* * * *}$ & $\pm 28.5^{* * *}$ & $\pm 85.3^{* * *}$ \\
\hline \multirow{2}{*}{ Group 2} & 4.29 & 0.19 & 0.46 & 105.0 & 94.7 & 255.1 \\
\hline & \pm 0.38 & \pm 0.06 & \pm 0.12 & $\pm 23.8^{* * *}$ & $\pm 23.4^{* * *}$ & $\pm 95.6^{* * *}$ \\
\hline \multirow{2}{*}{ Group 3} & 4.33 & 0.15 & 0.50 & 110.3 & 95.5 & 233.3 \\
\hline & \pm 0.52 & \pm 0.02 & \pm 0.13 & $\pm 45.4^{* * *}$ & $\pm 19.9^{* * *}$ & $\pm 43.2^{* * *}$ \\
\hline \multirow{3}{*}{ Group 4} & 5.11 & 0.18 & 0.49 & 115.6 & 83.8 & 210.8 \\
\hline & \pm 1.36 & \pm 0.02 & \pm 0.09 & $\pm 48.6^{* * *}$ & $\pm 31.0^{* * *}$ & $\pm 91.5^{* * *}$ \\
\hline & & & Day 42 & & & \\
\hline \multirow{2}{*}{ Group 1} & 5.87 & 0.20 & 0.45 & 97.5 & 121.4 & 521.4 \\
\hline & $\pm 0.83^{* * *}$ & \pm 0.02 & \pm 0.09 & \pm 11.3 & \pm 18.4 & $\pm 128.1^{* * *}$ \\
\hline \multirow{2}{*}{ Group 2} & 6.17 & 0.19 & 0.48 & 90.9 & 116.4 & 496.1 \\
\hline & $\pm 0.96^{* * *}$ & \pm 0.03 & \pm 0.06 & \pm 19.7 & \pm 25.9 & $\pm 121.7^{* * *}$ \\
\hline \multirow{2}{*}{ Group 3} & 5.92 & 0.17 & 0.50 & 93.4 & 106.8 & 497.4 \\
\hline & $\pm 0.62^{* * *}$ & \pm 0.04 & \pm 0.09 & \pm 20.0 & \pm 22.8 & $\pm 129.3^{* * *}$ \\
\hline \multirow{2}{*}{ Group 4} & 6.37 & 0.18 & 0.52 & 88.1 & 117.0 & 519.0 \\
\hline & $\pm 0.92^{* * *}$ & \pm 0.04 & \pm 0.09 & \pm 19.9 & \pm 19.7 & $\pm 111.1^{* * * *}$ \\
\hline
\end{tabular}

Results are presented as mean \pm S.D., $\mathrm{n}=15$

Significant differences at the day 21 vs. day 36 , and the day 36 vs. day $42(* * * P<0.001)$

confirm the hypothesis that a large portion of absorbed SelPlex escaping from degradation to $\mathrm{H}_{2} \mathrm{Se}$ is non-specifically incorporated into the structural proteins of muscles. In addition, Petrovič et al. (2010) found in the same experiment that the concentration of Se in the breast and thigh muscles was significantly increased in groups of broilers fed selenized yeast compared to sodium selenite, and age dependent changes of this index were found in both muscles only between the $1^{\text {st }}$ vs. $2^{\text {nd }}$ sampling. Similarly, no significant differences were shown in the form of selenium supplemented and GSH-Px activity in blood of adult poultry (Kuricová et al. 1999; Petrovič et al. 2006). Contrary to our findings, Wang and Xu (2008) found that the activity of GSH-Px in plasma was significantly higher $(P<0.05)$ in young broiler chickens fed selenized yeast compared to sodium selenite.

No differences were observed in the activities of AST, ALT, $\gamma \mathrm{GT}, \mathrm{ALP}, \mathrm{LDH}, \mathrm{CPK}$ between the groups of broilers at the age of 21,35 and 42 days. The activity of AST and ALT in blood was influenced by the form of selenium (Peric et al. 2009) when supplemented individually in poultry diet. Only age dependent changes in the activity of AST, ALP, LDH and CPK were found in our experiment (Table 4). A decreasing trend in the activity of ALP and an increasing 
tendency in the activity of AST, LDH and CPK in the blood plasma between the samplings were observed. These changes could have a close relation to the higher amount of $\mathrm{Cu}$ and $\mathrm{Mn}$ in the breast and thigh muscles on day 21 of life compared to the birds aged 42 days that were included in the same study (Petrovič et al. 2010). All these changes can reflect a notable development of parenchymatous organs and the bones of broilers as well as higher efficiency of lipid metabolism in the first 3 weeks of their life. The close relations between the lower amount of $\mathrm{Cu}$ and $\mathrm{Mn}$ associated with the decreasing metabolism of lipids in the organism of chickens were demonstrated by Kaya et al. (2006) and Lu et al. (2006 and 2007), respectively. Wiese et al. (1939) and Combs et al. (1942) found that the manganese and phosphatase activity play an interdependent role in the development and growth of bones of broilers. Significantly higher concentration of $\mathrm{Mn}$ in the breast and thigh muscles $(P>0.001)$ between the $1^{\text {st }} v \mathrm{vs} 2^{\text {nd }}$ sampling was reported in the same study published previously (Petrovič et al. 2010). This was accompanied by significantly elevated activity of ALP in the blood serum of broilers at the day 21 compared to the day 35 . It indicates that both aforementioned processes are very efficient in the first 3 weeks of the broiler's life.

In conclusion, restriction of the amounts of $\mathrm{Cu}, \mathrm{Fe}, \mathrm{Zn}$ and $\mathrm{Mn}$ supplemented in diet in the proteinated form had the same effects on the examined haemathological, immunological and enzymatic indices (except for GSH-Px) in the blood serum of broilers at the $21^{\text {st }}, 35^{\text {th }}$ and $42^{\text {nd }}$ day of life as the feeding of diet with recommended doses of these trace elements in the form of their inorganic salts. No differences due to the form of Se administered were found in these indices. The activity of GSH-Px was significantly higher in the groups of birds supplemented with sodium selenite only at the $21^{\text {st }}$ day of life, thereafter no differences in this index were found indicating that the GSH-Px activity reaches a plateau in all groups of broilers. On the other hand, age-dependent changes were observed in some of the studied indices, but the different dietary supplementation did not influence these changes within the experimental groups.

\section{Vplyv suplementácie stopových prvkov do diéty na sledované krvné, imunologické a enzymatické ukazovatele $v$ krvi v závislosti na veku broilerových kurčiat}

Štúdia sa zaoberá vplyvom dopíňania $\mathrm{Cu}, \mathrm{Zn}, \mathrm{Fe}, \mathrm{Mn}$ a Se do diéty na sledované hematologické, imunologické a enzymatické ukazovatele v krvi broilerových kurčiat vo veku 21 , 35 a 42 dní. Diéta pre prvú a druhú skupinu bola suplementovaná rovnakým množstvom anorganických foriem prvkov (síran med'natý $5 \mathrm{mg} \cdot \mathrm{kg}^{-1}$ sušiny, síran železnatý, oxid zinočnatý, oxid manganistý $50 \mathrm{mg} \cdot \mathrm{kg}^{-1}$ sušiny), kým Se bol dotovaný ako seleničitan sodný (1. skupina) alebo selenizované kvasnice (2. skupina) v dávke $0.3 \mathrm{mg} \cdot \mathrm{kg}^{-1}$ sušiny. Kŕmna dávka pre tretiu a štvrtú skupinu bola tvorená rovnakou bazálnou diétou, ale organické formy stopových prvkov boli podávané $\mathrm{v}$ značne znížených množstvách (Bioplex $\mathrm{Cu}$ $2.5 \mathrm{mg} \cdot \mathrm{kg}^{-1}$ sušiny, Bioplex Fe, Bioplex Zn, Bioplex Mn $10 \mathrm{mg} \cdot \mathrm{kg}^{-1}$ sušiny). Selén bol podávaný v rovnakej dávka a formách ako prvým dvom skupinám broilerových kurčiat. Suplementácia diéty zníženými dávkami organických foriem stopových prvkov mala rovnaký efekt na sledované hematologické, imunologické a enzymatické indexy, ako skrmovanie diéty dopíňanej doporučovanými dávkami ich anorganických solí. Vo veku 21 dní bola aktivita GSHPx významne vyššia $\mathrm{v}$ skupinách broilerov kŕmených diétou suplementovanou seleničitanom sodným $(P>0,001)$, potom už nebol zistený žiaden vplyv dopĺnanej formy Se na aktivitu GSHPx. To naznačuje, že GSH-Px bola plne saturovaná selénom na 21., 35. a 42. deň experimentu, $\mathrm{s}$ výnimkou 21 . dňa v oboch skupinách suplementovaných selénizovanými kvasnicami. Okrem toho, boli zistené významné na veku závislé zmeny v sledovaných krvných ukazovatel'och, ktoré ale neboli ovplyvnené nami podávanými diétami. Na základe získaných výsledkov môžeme konštatovat', že dávky organických foriem stopových prvkov doplńaných do diéty pre broileri môžu byt' zredukované na 50\% (Bioplex Cu) a 20\% (Bioplex Fe, Bioplex Zn and Bioplex Mn) bez ovplyvnenia študovaných krvných parametrov. 


\section{Acknowledgement}

Supported by Grant Agency for Science, VEGA of the Slovak Republic, Grant No. 1/0614/09

\section{References}

Allgöwer M, Schoenenberger GA, Sparkes BG 1995: Burning the largest immune organs. Burns 21: 7-47

Arthur JR, Boyne R 1985: Superoxide-dismutase and glutathione-peroxidase activities in neutrophils from selenium deficient and copper deficient cattle. Life Sci 36: 1569-1575

Barta O, Barta V, Pierson FW 1992: Optimum condition for the chicken lymphocyte transformation test. Avian Dis 36: $945-955$

Bozkaya LA, Ozturk-Urek R, Aydemir T, Tarhan L 2001: Effects of Se, Cu and Se plus vitamin E deficiency on the activities of CuZnSOD, GSH-Px, CAT and LPO levels in Chicken Erythrocytes. Cell Biochem Funct 19: $153-157$

Chandra RK, McBean LD 1994: Zinc and immunity. Nutrition 10: 79-80

Combs GF, Norris LC, Heuser GF 1942: The interrelationship of manganese, phosphatase and vitamin D in the bone development. J Nutr 23: 131

Fekete SG, Kellems RO 2007: Interrelationship of feeding with immunity and parasitic infection: a review. Vet Med - Czech 52: 131-143

Goldová M, Revajová V, Pistl J, Levkut M, Wahshal E, Csizsmárová G, Loószová A 2001: Eimeria colchici and immunocompetent cells in specific and non-specific hosts. Acta Parazitol 46: 39-44

Kaya A, Altiner A, Ozpinar A 2006: Effect of copper deficiency on blood lipid profile and haematological parameters in broilers. J Vet Med Series A - Physiol Pathol Clin Med 53: 399-404

Kuricová S, Boldižárová K, Grešáková L', Levkut M, Leng L' 2003: Chicken selenium status when fed a diet supplemented with Se-yeast. Acta Vet Brno 72: 339-346

Lasher HN, Shane SM 1994: Infectios bursal disease. World Poult Sci J 50: 133-166

Leeson S, Caston L 2003: Using minimal supplements of trace minerals as a method of reducing trace mineral content of poultry manure. Anim Feed Sci Tech 142: 339-347

Lu L, Ji C, Luo XG, Liu B, Yu SX 2006: The effect of supplemental manganese in broiler diets on abdominal fat deposition and meat quality. Anim Feed Sci Tech 129: 49-59

Lu L, Luo XG, Ji C, Liu B, Yu SX 2007: Effect of manganese supplementation and source on carcass traits, meat quality, and lipid oxidation in broilers. J Anim Sci 85: 812-822

Munoz C, Rios E, Olivos J, Brunser O, Olivares M 2007: Iron, copper and immunocompetence. Br J Nutr 98: S24-S28

Nollet L, Huyghebaert G, Spring P 2008: Effect of different levels of dietary organic (Biolpex) trace minerals on live performance of broiler chickens by growth phases. J Appl Poultry Res 17: 109-115

Nollet L, Van der Klis JD, Lensing M, Spring P 2007: The effect of replacing inorganic with organic trace minerals in broiler diets on productive performance and mineral excretion. J Appl Poultry Res 16: 592-597

Nollet L, Wakerman W, Belyavin C 2005: Replacement of inorganic Cu, Mn, Fe and Zn with Bioplex on growth performance and faecal mineral excretion in broilers. In Proc 15th Eur Symp Poult Nutr, Balatonfüred, Hungary, p. 173-175

Ozturk-Urek R, Bozkaya LA, Tarhan L 2001: The effects of some antioxidant vitamin- and trace elementsupplemented diets on activities of SOD, CAT, GSH-Px and LPO levels in chicken tissues. Cell Biochem Funct 19: 125-132

Peric L, Nollet L, Miloševic N, Žikic D 2006: Effect of Bioplex and Sel-Plex substituting inorganic trace mineral sources on performance of broilers. Arch Geflügelk 71: 122-129

Peric L, Milosevic N, Zikic D, Kanacki Z, Dzinic N, Nollet L, Spring P 2009: Effect of selenium sources on performance and meat characteristics of broiler chickens. J Appl Poult Res 18: 403 - 409

Petrovič V, Boldižárová K, Faix Š, Mellen M, Arpašová H, Leng L' 2006: Antioxidant and selenium status of laying hens fed with diets supplemented with selenite or Se-yeast. J Anim Feed Sci 15: 435-445

Petrovič V, Nollet L, Kováč G 2010: Effect of dietary supplementation of trace elements on the growth performance and their distribution in the breast and thigh muscles depending on the age of broilers. Acta Vet Brno 79: 203-209

Sandstead HH 1994: Understanding zinc: recent observations and interpretations. J Lab Clin Med 124: $322-327$

Schrauzer GN 2000: Selenomethionine: A review of its nutritional significance, metabolism and toxicity. J Nutr 130: $1653-1656$

Ševčíková Z, Leng L, Revajová V, Pistl J, Kuricová S, Levkut M 2005: Immune response of chickens to feed supplementation with selenium. Folia Vet 49: 70-76

Sevcikova S, Skrivan M, Dlouha G, Koucky M 2006: The effect of selenium source on the performance and meat quality of broiler chickens. Czech J Anim Sci 51: 449-457

Wang YB, Xu BH 2008: Effect of different selenium source (sodium selenite and selenium yeast) on broiler chickens. Anim Feed Sci Tech 144: 306-314

Wiese AC, Johnson BC, Elvehjem CA, Hart EB, Halpin JG 1939: A study of blood and bone phosphatase in chick perosis. Ibid 127: 411 